\title{
Absinthe makes the art grow stronger
}

John Molion

Vincent van Gogh: Chemicals, Crisis, and Creativity. By Wilfred Niels Arnold. Birkhäuser: 1992. Pp. 332. DM98, £37.20, \$49.50.

BOOKS on the ailments of the distinguished dead form a recognizable literary genre; and there is a whole sub-genre devoted to the madness of Vincent van Gogh. During the last three years of his life - a period that saw the painting of some of his finest works - van Gogh had several episodes of mental disturbance. Among the diagnoses offered have been schizophrenia, idiopathic epilepsy, manic-depressive psychosis, syphilis, Ménière's disease and intoxication by metal salts. Psychoanalysts still trace his instability to his relationship with his parents and to the stillborn infant, Vincent, who preceded him by one year. Wilfred Arnold's hypothesis is that van Gogh suffered from the rare metabolic disorder acute intermittent porphyria, and that his attacks were precipitated by indulgence in absinthe.

Acute intermittent porphyria arises from mutations in the gene that codes for porphobilinogen deaminase, the third enzyme in the pathway for the biosynthesis of haem. The inheritance is autosomal dominant with variable penetrance. An almost invariable symptom is abdominal pain, and muscular weakness, psychosis and seizures are common. The attacks begin after puberty and are intermittent; and indeed around 90 per cent of heterozygotes may pass through life with only half the normal level of the enzyme and yet not show symptoms. Under unstressed conditions, it is thought, the rate of flux of substrates through the haem pathway is below the threshold at which the affected enzyme becomes rate-limiting. Any increased demand for haem in the liver will induce $\delta$-aminolevulinic acid synthase, make porphobilinogen deaminase rate-limiting and lead to the accumulation of intermediates. Fasting or drugs may precipitate such an attack.

Van Gogh's doctors have left us only the tersest clinical notes, but the artist was himself much concerned with his health and it is a frequent topic in his letters to his brother Theo. Arnold supports his theory with a detailed examination of the letters; and, as his theory requires, he also assesses the evidence that Theo and other members of the family suffered from the same hereditary condition. He supposes that van Gogh's attacks were precipitated by neglect of meals, by the use of camphor against insomnia and in particular by drinking absinthe, the fashionable clear green

liqueur that turned to an opalescent pale yellow when diluted with water. An absinthe bottle appears in more than one of van Gogh's paintings, and we have Paul Signac's account of how van Gogh "would take his seat on the terrace of a café. And the absinthes and brandies would follow each other in quick succession." In the southern department of Bouches-du-Rhône, where van Gogh lived from 1888 to 1891 , the average annual consumption of absinthe was a remarkable 2.45 litres per head, and it was only in the twentieth century that the toxic effects of the liqueur led to a ban. Its most sinister ingredient was thujone, a terpene derived from wormwood (Artemisia absinthium). A standard test for drugs that induce porphyria is to measure the induction of $\delta$ aminolevulinic acid synthase in liver cells from fetal chickens; and Arnold reports a positive result when testing thujone and camphor.

It makes a good read. But ultimately the evidence is circumstantial. Although Arnold lists a number of letters that refer to 'gastrointestinal complaints', the relevant passages in fact speak mostly of 'weakness of the stomach' rather than severe abdominal pain. And notably missing from this detective story is the smoking urine. I. MacAlpine and R. Hunter in their study of putative porphyrics in the British royal family

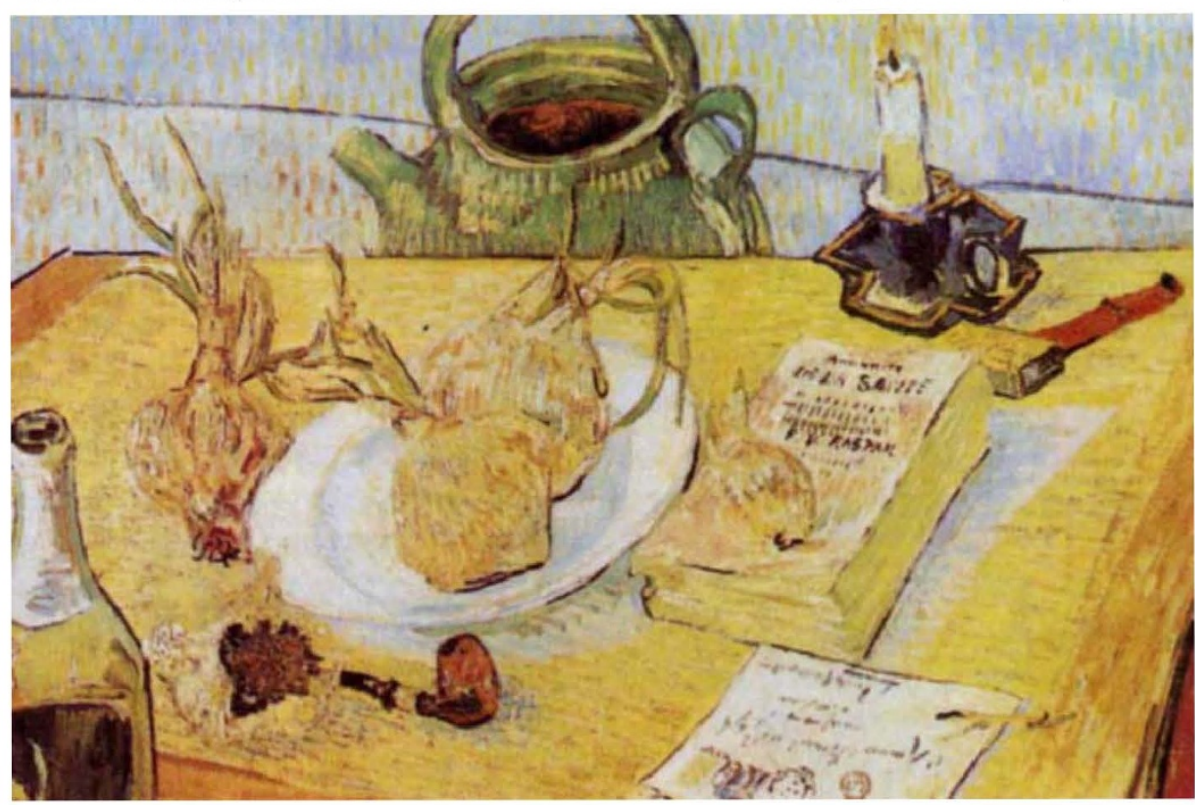

Damaging diet - van Gogh's Still LIfe, Drawing Board with Onions, Raspall's Book, Absinthe Bottle etc. (1889, St Rémy, oil on canvas).

(George III and the Mad-Business, Allen Lane, 1969; curiously uncited by Arnold) were able to find contemporary reports of discoloured urine not only in the case of George III, but even in the case of his seventeenth-century ancestor James I. Arnold has found no such reference in van Gogh's letters. He explains this away rather lamely: van Gogh probably pissed in the fields and his urine seldom had the chance to stand around and turn the opaque port-wine colour that reveals the presence of porphyrins. Yet van Gogh lived in the heyday of the vase de nuit and his crises were largely spent in the hospital at Arles or the asylum at St Rémy.
The polymerase chain reaction will take some of the sport out of this genre of medical history. For the famous and the infamous have often left fragments of themselves behind, and it is possible nowadays to amplify sections of suspect genes from only micrograms of DNA allowing a test, for example, of whether Abraham Lincoln owed his tallness to Marfan's syndrome (see V. A. McKusick, Nature 352, 279; 1991). The gene for porphobilinogen deaminase has been sequenced and several mutations that give rise to acute intermittent porphyria are already known. So that amputated ear, had it been preserved, would have given us a firm answer. But the hospital at Arles kept it for a year and then threw it away.

John Mollon is in the Department of Experimental Psychology, University of Cambridge, Cambridge CB2 3EB, UK. 